\title{
Rhinolekos capetinga: a new cascudinho species (Loricariidae, Otothyrinae) from the rio Tocantins basin and comments on its ancestral dispersal route
}

\author{
Fábio F. Roxo', Luz E. Ochoa', Gabriel S. C. Silva', Claudio Oliveira' \\ I Universidade Estadual Paulista, Departamento de Morfologia, Laboratório de Biologia e Genética de Peixes, \\ Rubiäo Júnior s/n, 18618970 Botucatu, São Paulo State, Brazil \\ Corresponding author: Fábio F. Roxo (roxoff@hotmail.com.br)
}

Academic editor: N. Bogutskaya | Received 15 October 2014 | Accepted 29 January 2015 | Published 4 February 2015

http://zoobank.org/F6296A27-8652-4669-A095-96A9A1D06C49

Citation: Roxo FF, Ochoa LE, Silva GSC, Oliveira C (2015) Rhinolekos capetinga: a new cascudinho species (Loricariidae, Otothyrinae) from the rio Tocantins basin and comments on its ancestral dispersal route. ZooKeys 481: 109-130. doi: $10.3897 /$ zookeys.481.8755

\begin{abstract}
The present study deals with the description of a new species of Rhinolekos. It can be distinguished from its congeners by having 31 vertebrae, the anterior portion of the compound supraneural-first dorsal-fin proximal radial contacting the neural spine of the $9^{\text {th }}$ vertebra, the absence of transverse dark bands in the pectoral, pelvic and anal-fin rays, 24-28 plates in the dorsal series, the lack of odontodes on the ventral tip of the snout, the absence of accessory teeth, a greater prenasal length, a smaller head length, and by a greater snout length. Rhinolekos capetinga is restricted to the headwaters of the rio Tocantins and it is the first species of this genus in the Amazon basin. Additionally, we present a brief discussion of a biogeographic scenario that may explain the dispersal of the new species from the rio Paranaíba to the rio Tocantins basin. We suggest that the ancestral lineage of $R$. capetinga reached the rio Tocantins from portions of the rio Paranaíba at the end of the Miocene, about 6.3 Mya (4.1-13.9 Mya 95\% HPD), probably as a result of headwater capture processes among adjacent drainages.
\end{abstract}

\section{Keywords}

Biodiversity, Freshwater, Neotropical fish, South America, Taxonomy

Copyright Fábio F. Roxo et al. This is an open access article distributed under the terms of the Creative Commons Attribution License (CC BY 4.0), which permits unrestricted use, distribution, and reproduction in any medium, provided the original author and source are credited. 


\section{Introduction}

Otothyrinae sensu Chiachio et al. (2008) is one of the most diverse and widespread members of Loricariidae, and is composed of about 97 species (Eschmeyer and Fong 2014). Fishes of this subfamily are characterized by morphological specializations such as the presence of metapterygoid channel, the ventral margin of preopercle medially reflected, the rostral plate with posterior notch articulated with mesethmoid, the fourth infraorbital expanded ventrally, and the almost complete fusion of pectoral dermal bony plates forming a strong pectoral armor (Schaefer 1998; Chiachio et al. 2008). In the last fifteen years, new genera and species have been described and assigned (Roxo et al. 2014a) to the subfamily Otothyrinae (e.g. Gymnotocinclus Carvalho, Lehmann \& Reis, 2008; Rhinolekos Martins \& Langeani, 2011a), indicating that the great diversity of this group still remains fairly known (Martins and Langeani 2011a).

Rhinolekos is the most recently described genus of Otothyrinae and differs from its members, mainly by having the anterior portion of the compound supraneural-first dorsal-fin proximal radial contacting the neural spine of the $9^{\text {th }}$ or $10^{\text {th }}$ vertebrae and by the presence of the lateronasal plate. Currently, Rhinolekos includes three valid species: R. britskii Martins \& Langeani, 2011a, R. schaeferi Martins \& Langeani, 2011a and $R$. garavelloi Martins \& Langeani, 2011a, all of which were described from drainages of the rio Paranaíba (upper rio Paraná basin).

Furthermore, several authors discussed the historical dispersal of the ancient fauna among adjacent drainages of South America Platform (e.g. Ribeiro 2006; Albert and Reis 2011) and specifically species of the families Hypoptopomatinae, Neoplecostominae, and Otothyrinae (e.g. Roxo et al. 2012; Roxo et al. 2014a). The geological process responsible for this distribution pattern is head water captures (also known as stream capture or stream piracy). This is a geomorphological process by which the flow of part of a stream or river drainage basin is diverted into neighboring basin. River capture may facilitate the dispersal of fish species among adjacent drainage and can have profound consequences in isolated local fauna, which watershed boundaries strongly limit their dispersal (Grant et al. 2007; Muneepeerakul et al. 2008; Bertuzzo et al. 2009).

Recently, during collecting expeditions in small tributaries of the rio Tocantins, the major drainage of the Brazilian Shield (Carvalho and Albert 2011), an undescribed species of Otothyrinae, which meets the diagnosis of Rhinolekos, was collected and is formally described in the present study. Moreover, we used a time calibrated phylogenetic analysis and parametric biogeographic methods based on available data of Roxo et al. (2014a) to estimate ancestral geographic ranges and hypothesize when the new species reached the rio Tocantins from sections of the rio Paranaíba, probably as a result of head water capture events between these two hydrographic systems in Late Miocene. 


\section{Material and methods}

\section{Morphological analysis}

After collection, fish were anesthetized using $1 \%$ benzocaine in water, fixed in $10 \%$ formaldehyde, and preserved in 70\% ethanol for morphological study. Institutional acronyms follow Fricke and Eschmeyer (2014). Vouchers of the morphological study were deposited in the collection of the Laboratório de Biologia e Genética de Peixes (LBP) and Museu de Zoologia da Universidade de São Paulo (MZUSP), Brazil. Measurements and counts were taken on the left side of specimens. Measurements followed Boeseman (1968) with modifications of Armbruster and Page (1996), Schaefer and Provenzano (1993), and Ribeiro et al. (2005) and were taken point to point to the nearest $0.1 \mathrm{~mm}$ with digital calipers. Meristic data include numbers of premaxillary and dentary teeth, dorsal, middorsal, median, mid-ventral and ventral plates following Schaefer (1997). Abbreviations used in the text followed Carvalho and Reis (2009). Specimens were cleared and stained (c\&s) according to the method of Taylor and Van Dyke (1985). Head plate and osteology nomenclature followed Schaefer (1997). Dorsal-fin ray counts include spinelet as the first unbranched ray. Vertebral counts also include the five vertebrae that comprise the Weberian apparatus. The compound caudal centrum $(\mathrm{PU} 1+\mathrm{U} 1)$ was counted as one element. Zoological nomenclature follows the International Code of Zoological Nomenclature (International Commission on Zoological Nomenclature 1999).

\section{Molecular analysis}

We used Diplomystes mesembrinus to root our phylogeny. Additionally, samples of Corydoras imitator, Corydoras oiapoquensis, Hoplosternum littorale, Callichthys callichthys, Astroblepus sp. 1 and Astroblepus sp. 2, Hemipsilichthys gobio, H. papillatus, Delturus parahybae, Rineloricaria lanceolata, Spatuloricaria sp. 1, Hypostomus ancistroides, H. nigromaculatus and $H$. microstomus were used as additional outgroups. We included in the analysis 155 specimens representing 115 loricariid species (see Suppl. material 3-Table S1 to all species names, localities, deposits in museums and GenBank accession numbers).

Vouchers of the molecular study were deposited at the collection of the Laboratório de Biologia e Genética de Peixes (LBP); the Museu de Ciências e Tecnologia, Pontifícia Universidade Católica do Rio Grande do Sul (MCP); the Núcleo de Pesquisas em Limnologia, Ictiologia e Aquicultura (NUP); and the Museum of Natural History of the City of Geneva (MHNG).

\section{Sequencing}

Total DNA was extracted from ethanol preserved muscle samples with the DNeasy Tissue Kit (Qiagen), following manufacturer's instructions. Partial sequences of the 
genes 16S rRNA (Kocher et al. 1989), cytochrome $b$ (Cytb) (Oliveira et al. 2011), cytochrome c oxidase subunit I (COI) (Ward et al. 2005) and F-reticulon 4 (Chiachio et al. 2008) were amplified using polymerase chain reaction (PCR) with the primers described in Suppl. material 4 - Table S2. Amplifications were performed in a total volume of $12.5 \mu \mathrm{l}$ with $1.25 \mu \mathrm{l}$ of $10 \mathrm{X}$ buffer $(10 \mathrm{mM}$ Tris- $\mathrm{HCl}+15 \mathrm{mM} \mathrm{MgCl} 2)$, $0.5 \mu \mathrm{l}$ dNTPs (200 $\mathrm{nM}$ of each), $0.5 \mu \mathrm{l}$ each $5 \mathrm{mM}$ primer, $0.05 \mu \mathrm{l}$ Platinum ${ }^{\odot}$ Taq Polymerase (Invitrogen), $1 \mu \mathrm{l}$ template DNA (12 ng), and $8.7 \mu \mathrm{lddH} 2 \mathrm{O}$. The PCR reactions consisted of $30-40$ cycles, $30 \mathrm{~s}$ at $95^{\circ} \mathrm{C}, 15-30 \mathrm{~s}$ at $48-58{ }^{\circ} \mathrm{C}$, and $45-90 \mathrm{~s}$ at $72^{\circ} \mathrm{C}$. Nested-PCRs were used to amplify the nuclear marker; the first amplification was performed using the primers Freticul4-D and Freticul4-R with a total volume of $12.5 \mu \mathrm{l}$ for $30-40$ cycles $\left(30 s\right.$ at $95^{\circ} \mathrm{C}, 30 s$ at $48^{\circ} \mathrm{C}$, and $135 s$ at $72^{\circ} \mathrm{C}$ ); the second amplification was performed using the primers Freticul 4 D2 and Freticul 4 R2 with a total volume of $12.5 \mu \mathrm{l}$ for $30-40$ cycles $\left(30 \mathrm{~s}\right.$ at $95^{\circ} \mathrm{C}, 30 \mathrm{~s}$ at $53-54^{\circ} \mathrm{C}$, and $135 \mathrm{~s}$ at $72{ }^{\circ} \mathrm{C}$ ). All PCR products were first visually identified on a $1 \%$ agarose gel and then purified using ExoSap-IT ${ }^{\oplus}$ (USB Corporation) following instructions of the manufacturer. The purified PCR products were sequenced using the "Big DyeTM Terminator v3.1 Cycle Sequencing Ready Reaction Kit" (Applied Biosystems), purified again by ethanol precipitation and loaded on an automatic sequencer 3130-Genetic Analyzer (Applied Biosystems) in the Instituto de Biociências, Universidade Estadual Paulista, Botucatu, São Paulo.

\section{Phylogenetic analysis}

The phylogenetic analysis was performed according to Roxo et al. (2014a) (Suppl. material 1 - Fig. S1). All individual sequences for each species were initially analyzed using the software program BioEdit 5.0.9 (Hall 1999) and consensus sequences were obtained. All sequences for each gene were independently aligned using MUSCLE (Edgar 2004) under default parameters and the alignments inspected by eye for any obvious misalignments. After that, sequences of all genes were concatenated to perform all phylogenetic and biogeography analysis.

Maximum likelihood analyses were performed using RAxML Web-Servers (Stamatakis et al. 2008). RAxML implements a faster algorithm of heuristic searches with bootstrap pseudoreplicates (RBS). Bootstrap (BS) resampling (Felsenstein 1985) was applied to assess support for individual nodes using 1,000 replicates. Random starting trees were used for each independent ML tree search and all other parameters were set on default values.

Bayesian inference (BI) (Huelsenbeck and Ronquist 2001) was performed evaluating alternative tree topologies through the estimation of posterior probabilities $(\mathrm{P})$ using MrBayes v.3.0 (Ronquist and Huelsenbeck 2003). The ML tree obtained from ML analysis was used as a starting three for the Markov chain Monte Carlo searches. Eight chains were run simultaneously for 100,000,000 generations and every $1000^{\text {th }}$ generation a tree was sampled. The above analysis was performed twice. The distribution of 
log-likelihood scores was examined to determine stationary phase for each search and to decide if extra runs were required to achieve convergence, using the program Tracer 1.5 (Rambaut and Drummond 2007a). All sampled topologies beneath the asymptote $(25,000,000$ generations) were discarded as part of a burn-in procedure, and the remaining trees were used to construct a 50\% majority-rule consensus tree in TreeAnnotator v1.7.5 (Rambaut and Drummond 2007b).

\section{Time calibrated phylogeny and hypothesis on the ancestor}

The time calibrated phylogeny was performed according to Roxo et al. (2014a) (Suppl. material 2 - Fig. S2). The uncorrelated relaxed molecular clock was calibrated using BEAST (Bayesian Evolutionary Analysis Sampling Trees) v1.6.2 (Drummond and Rambaut 2007). Two fossil calibration points were used to constrain divergence times for all clades of the phylogenetic tree. The first calibration point was implemented as a normally distributed prior, with an offset of 125 million years ago $(\mathrm{Ma})$, and a standard deviation of 15 million years. These date-estimate parameters were selected to match current knowledge of the timing of siluriform origins. Information from the stratigraphic record and geographic distributions of living taxa indicate an origin for Siluriformes during the Lower Cretaceous (145-100 Ma; Lundberg 1993; Sullivan et al. 2006; Lundberg et al. 2007). We used a birth-death model for speciation likelihood and a starting tree obtained from ML. The analysis was run for 100 million generations and sampled every $1000^{\text {th }}$ generation. Stationarity and sufficient mixing of parameters (ESS $>200$ ) was checked using Tracer v1.5 (Rambaut and Drummond 2007a). A consensus tree was built using TreeAnnotator v1.6.2 (Rambaut and Drummond 2007b).

Data on the geographic distributions of species were taken from the original species descriptions and information available at the Catalog of Eschmeyer (2014). We assigned taxa to geographic areas using the ecoregion classifications of Vari and Malabarba (1998) and Chiachio et al. (2008), within the following five biogeographic regions: A, Atlantic Coastal Drainages of Southeastern Brazil; B, Upper Paraná Basin; C, Paraguay, Lower Paraná and Uruguay basins; D, Amazon and Orinoco basins; E, São Francisco basin and Coastal Drainages of Northeastern of Brazil (see Roxo et al. 2014a for more details about biogeographic area classifications). The new species $R$. capetinga is assigned to the $\mathrm{D}$ area (Amazon and Orinoco basins) in the present paper.

The maximum-likelihood analysis of biogeographic history was performed in Lagrange v2.0 (Ree et al. 2005; Ree and Smith 2008) using all available data and parameters of Roxo et al. (2014a). Four DEC models were tested to estimate distribution ranges inherited by the descending lineages at each node of the tree. The differences between the models are in the rate of dispersal among adjacent and no adjacent areas (see Suppl. material 5 - Table S3 for the likelihood values and dispersal rate among adjacent and no adjacent areas for each model). The model that obtained the highest ML values was model 3 (M3) that constrained the dispersal rates between adjacent areas at 0.5 and areas separated by one or more intercalated areas at 0.0001 . 


\section{Results}

\section{Rhinolekos capetinga sp. $\mathbf{n}$.}

http://zoobank.org/53CB690E-E969-4C06-8C1E-4991C103F19F

Figs 1, 3; Table 1

Rhinolekos sp. 1 - Roxo et al. 2014a: 9(8) e105564 (phylogenetic relationships).

Holotype. MZUSP 116102, (male, 37.5 mm SL), Brazil, Goiás State, municipality of Água Fria de Goiás, córrego da Branca, drainage of the rio Tocantizinho, rio Tocantins basin, $14^{\circ} 53^{\prime} 47.2^{\prime \prime S}$, 47 $34^{\prime} 58.4^{\prime \prime W}, 30$ June 2014, FF Roxo, GSC Silva, LE Ochoa.

Paratypes. Brazil, Goiás State, rio Tocantins basin (56 specimens). LBP 17089 (1 male, $39.1 \mathrm{~mm} \mathrm{SL}$ ), municipality of Agua Fria de Goiás, córrego da Branca, drainage of the rio Tocantizinho, $14^{\circ} 57^{\prime} 01.6^{\prime \prime S}, 47^{\circ} 35^{\prime} 57.0^{\prime \prime W}, 21$ November 2012, R Devidé, BF Melo, JMH Martinez, GSC Silva; LBP 18996, (1 female, $24.1 \mathrm{~mm} \mathrm{SL}$ ), municipality of São João D’Aliança, córrego Roncador, drainage of the rio Tocantizinho, $14^{\circ} 43^{\prime} 51.3^{\prime \prime S}, 47^{\circ} 32^{\prime} 34.0^{\prime \prime W}, 30$ June 2014, FF Roxo, GSC Silva, LE Ochoa; LBP 19001 (15 females, 26.8-36.2 mm SL, 20 males, 39.5-30.2 mm SL, 3 c\&s, 37.2-32.6 mm SL, 9 unsexed juveniles not measured), collected with holotype. LBP 19466 (2 females, 36.5-37.1 mm SL) municipality of Água Fria de Goiás, córrego da Branca,

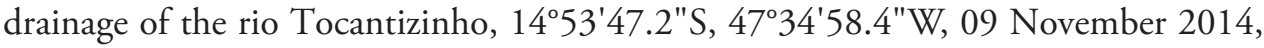
FF Roxo, LH Roxo, GSC Silva, LE Ochoa; MZUSP 113920 (2 females, 29.3-37.3 mm SL, 3 males, 30.4-39.0 mm SL), municipality of Água Fria de Goiás, córrego da

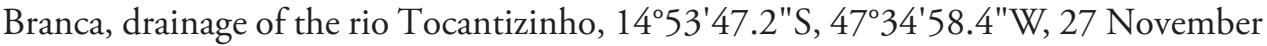
2012, OT Oyakawa, AM Zanata, P Camelier, M Melo.

Diagnosis. Rhinolekos capetinga differs from $R$. garavelloi and $R$. schaeferi in that it has a lower number of vertebrae, 31 (vs. 32) and the anterior portion of the compound supraneural-first dorsal-fin proximal radial contacts the neural spine at the $9^{\text {th }}$ vertebra (vs. $10^{\text {th }}$, Fig. 2a). The new species can be distinguished from $R$. britskii by the absence of transverse dark bands in the pectoral, pelvic and anal-fin rays (vs. present), lower number of plates in the dorsal series 24-28 (vs. 30-35), lack of odontodes on the ventral tip of the snout (vs. tip of snout completely covered by odontodes), and by having a greater prenasal length, $41-60 \%$ of HL (vs. 32-40\% of HL). Moreover, the new species differs from $R$. schaeferi by the absence of accessory teeth (vs. present) and from all congeners by the smaller head length, $20-27 \%$ of SL (vs. $28-32 \%$ of SL in $R$. britskii; $29-35 \%$ of SL in $R$. garavelloi; $29-32 \%$ of SL in $R$. schaeferi), and by the greater snout length, $61-85 \%$ of HL (vs. $52-57 \%$ of SL in $R$. britskii; $49-60 \%$ of SL in $R$. garavelloi; $53-59 \%$ of SL in $R$. schaeferi). It differs from $R$. britskii and $R$. garavelloi by the smaller caudal-peduncle depth, 6-9\% of SL (vs. 9-11\% of SL in R. britskii and $10-13 \%$ of SL in $R$. garavelloi); it differs from $R$. garavello $i$ by the smaller thoracic length $10-15 \%$ of SL (vs. $18-21 \%$ of SL), and by the smaller folded dorsal-fin length, $14-21 \%$ of SL (vs. $22-26 \%$ of SL). 


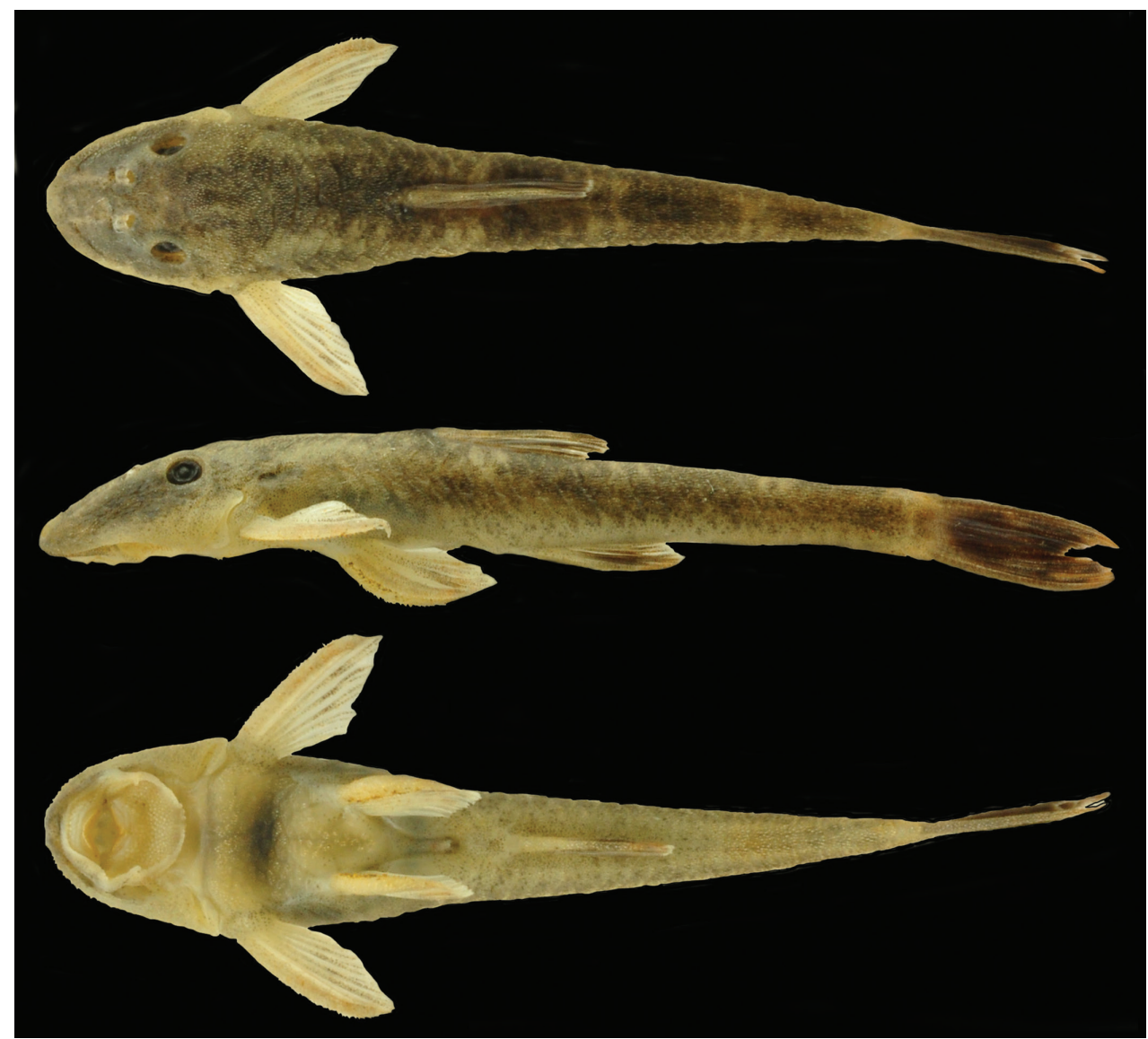

Figure I. Rhinolekos capetinga MZUSP 116102, holotype, male, 37.5 mm SL, Goiás State, rio Tocantins basin, Brazil.

Description. Morphometric and meristic data presented in Table 1. Maximum body length $39.1 \mathrm{~mm} \mathrm{SL}$; dorsal profile of head in lateral view convex to straight from upper part of rostrum to anterior margin of eyes, slightly curved from eyes to posterior margin of parieto supraoccipital, almost straight to dorsal-fin origin; dorsal profile of trunk almost straight, descending from base of dorsal-fin origin to caudal peduncle; ventral profile slightly concave from snout tip to pelvic-fin origin, slightly convex to caudal peduncle; greatest body depth at dorsal-fin origin; greatest body width at cleithral region, gradually decreasing towards snout and caudal-fin. Cross-section of caudal peduncle almost ellipsoid; rounded laterally and almost flat dorsally and ventrally.

Head rounded in dorsal view. Snout slightly pointed, its tip rounded, elongated (61-85\% of HL) and depressed in front of each nostril on dorsal surface. Anterior margin of snout covered with odontodes, except ventral tip of snout; odontodes of margin of snout similar in size to remaining ones found on head. Odontodes on head 
Table I. Morphometrics and meristic data for $R$. capetinga. SD, standard deviation.

\begin{tabular}{l|c|c|c|c}
\hline & \multicolumn{4}{|c}{ Rhinolekos capetinga, holotype and paratypes (n=30) } \\
\hline & Holotype & Range & Mean & SD \\
\hline SL & $\mathbf{3 7 . 5}$ & $\mathbf{2 2 . 9 - 3 9 . 1}$ & $\mathbf{3 4 . 3}$ & $\mathbf{3 . 6}$ \\
\hline Percents of SL & & & & \\
\hline Predorsal length & 42.2 & $38.9-49.9$ & 44.7 & 2.0 \\
\hline Preanal length & 53.4 & $48.2-60.3$ & 54.0 & 2.7 \\
\hline Prepectoral length & 26.2 & $19.1-26.2$ & 23.2 & 1.4 \\
\hline Prepelvic length & 33.3 & $31.5-39.5$ & 35.2 & 2.0 \\
\hline Postanal length & 34.4 & $28.0-38.7$ & 34.8 & 2.5 \\
\hline Thoracic length & 13.1 & $9.6-15.2$ & 12.9 & 1.5 \\
\hline Abdominal Length & 19.7 & $11.8-23.5$ & 19.2 & 2.2 \\
\hline Caudal peduncle depth & 6.6 & $5.8-8.6$ & 6.9 & 0.6 \\
\hline Head length & 21.6 & $19.6-26.6$ & 22.4 & 1.5 \\
\hline Head width & 22.1 & $17.6-26.6$ & 21.8 & 1.8 \\
\hline Head depth & 11.9 & $10.8-15.7$ & 12.8 & 1.0 \\
\hline Base of dorsal-fin length & 10.9 & $9.3-13.0$ & 10.5 & 1.0 \\
\hline Folded dorsal-fin length & 20.7 & $13.9-21.3$ & 19.1 & 1.4 \\
\hline Pectoral-fin unbranched ray length & 20.1 & $13.6-22.9$ & 19.9 & 1.9 \\
\hline Pelvic-fin unbranched ray length & 15.3 & $13.3-17.5$ & 15.6 & 1.2 \\
\hline Snout-opercle length & 21.8 & $18.8-26.3$ & 21.9 & 1.5 \\
\hline Percents of HL & & & & \\
\hline Snout length & 60.9 & $60.7-85.2$ & 72.4 & 5.8 \\
\hline Orbital diameter & 19.6 & $12.2-23.2$ & 17.1 & 2.3 \\
\hline Interorbital length & 45.4 & $40.4-55.8$ & 46.6 & 3.8 \\
\hline Prenasal length & 48.8 & $41.3-60.2$ & 51.4 & 4.4 \\
\hline Suborbital depth & 26.3 & $19.0-39.7$ & 25.6 & 4.5 \\
\hline Meristics & Holotype & Range & Mode & SD \\
\hline Left premaxillary teeth & 26 & $15-34$ & 22 & - \\
\hline Left dentary teeth & 24 & $14-31$ & 26 & - \\
\hline Dorsal plates & 27 & $24-28$ & 27 & - \\
\hline Mid-dorsal plates & 17 & $16-20$ & 18 & - \\
\hline Median plates & 25 & $23-27$ & 25 & - \\
\hline Ventral plates & $20-24$ & 22 & - \\
\hline
\end{tabular}

and trunk well defined and not forming longitudinal rows; eye small (12-23\% of $\mathrm{HL}$ ), dorsolaterally positioned; iris operculum not present; lips roundish and papillose; papillae uniformly distributed on base of dentary and premaxillary and slightly decreasing distally. Lower lip larger than upper lip; its border fringed; maxillary barbel present; Teeth slender and bicuspid; mesial cusp larger than lateral cusp; premaxillary teeth 15-34. Dentary teeth 14-30.

Dorsal fin ii,6-7; dorsal-fin spinelet short, roughly triangular shaped, locking mechanism non-functional; dorsal-fin origin slightly posterior of vertical through 

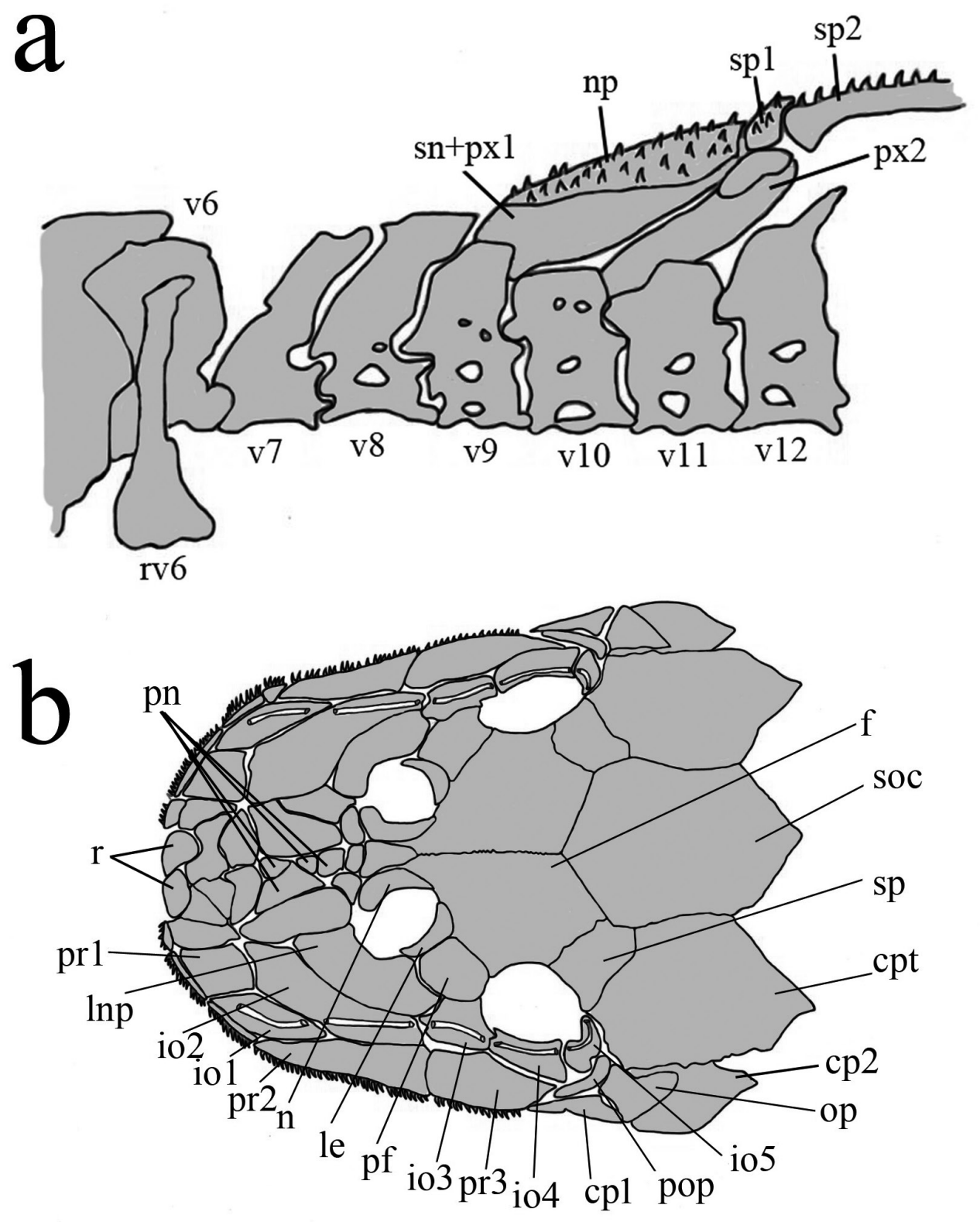

Figure 2. Rhinolekos capetinga, LBP 19001, paratype, $34.5 \mathrm{~mm}$ SL. a Anterior portion of axial skeleton and dorsal-fin supports (left side, lateral view). Vertebrae counts included five vertebrae of the Weberian apparatus. np nucal plate; rv6 rib of sixth vertebrae; px2 compound proximal and medial radial 2; $\mathbf{s n + p x 1}$ compound supraneural first dorsal-fin proximal radial; sp1 first dorsal-fin spinelet; sp2 second dorsal-fin spine; v6-12 vertebrae 6-12 b Skull of $R$. capetinga; f frontal; soc supraoccipital; cpt parietosupraoccipital; op opercle; io1-5 infraorbitals; pop preopercle; cp 1-2 cheek plates; pr 1-3 postrostral plates; pf prefrontal plates; le lateral ethmoid; $\mathbf{n}$ nasal; $\mathbf{l} \mathbf{p n}$ lateronasal plate; $\mathbf{r}$ rostral plate; pn prenasal; sp sphenotic. 


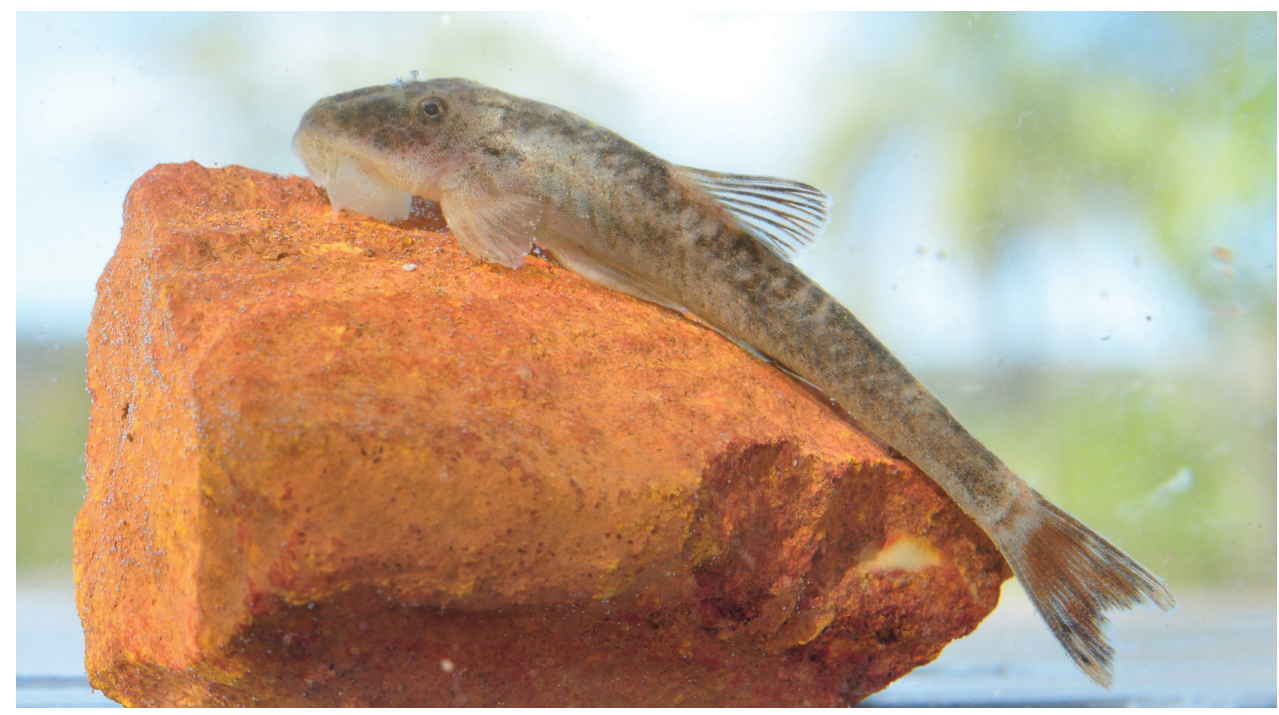

Figure 3. Rhinolekos capetinga, live specimen, MZUSP 116102, holotype, male, $37.5 \mathrm{~mm} \mathrm{SL}$, rio Tocantins basin, Goiás State, Brazil. Photo: FF Roxo.

pelvic-fin origin. Anterior portion of compound supraneural-first dorsal-fin proximal radial contacting neural spine of $9^{\text {th }}$ vertebrae (Fig. 2a). Tip of adpressed dorsal-fin rays slightly surpassing end of anal-fin base. Pectoral fin i,5-6; tip of longest pectoral-fin ray almost reaching to middle of adpressed pelvic-fin, when depressed. Pectoral axillary slit not present even in juveniles. Pectoral spine supporting odontodes anteroventrally; pelvic fin i,5; its tip not exceeding anal-fin origin when depressed in both sexes. Pelvicfin unbranched ray with dermal flap along its dorsal surface in males; anal fin i,5; its tip reaching $7^{\text {th }}$ and $8^{\text {th }}$ plate from its origin; Caudal fin i,14,i; distal margin forked; Adipose-fin absent. Total vertebrae 31 ( 3 c\&s).

Body covered with bony plates except on ventral part of head, around pectoral and pelvic-fin origin and on dorsal-fin base. Cleithrum and coracoid totally exposed; Arrector fossae partially enclosed by ventral lamina of coracoids. Abdomen entirely covered by plates in adults (about $25.0 \mathrm{~mm} \mathrm{SL}$ ); lateral plate series with elongate and large plates, formed by two lateral plate series, similar in size; median plates formed by four to five irregular plate series reaching anal shield. Lateral side of body entirely covered by plates; mid-dorsal and mid-ventral plates well developed, reaching typical adipose-fin region.

Parts of head osteology presented in Fig. 2b. Tip of snout formed by two square rostral plates. Nasal almost rectangular forming anterior medial nostril margin in contact posteriorly with frontals, and anterior and lateral margins contacting pre-nasals. Lateral surface of head formed by three posterior rostrum plates, second one large and triangular shaped. Complete infraorbital plate series, present mesial to posterior rostrum series, composed of five plates; fourth infraorbital expanded ventrally, all associated with latero-sensory canal system; first and second infraorbitals largest and 
fifth smallest. Large lateronasal plate mesial to second infraorbital, forming anterior distal nostril margin in contact anteriorly with prenasals and posteriorly with prefrontal. Preopercle present just ventral to fifth infraorbital; an elongated bone covered by latero-sensory canal. Subocular cheek plates present ventral to preopercle plate. Top of head composed of compound pterotic-supracleithrum, supraoccipital, prefrontal, frontal, and sphenotic; parieto-supraoccipital bearing fenestrae irregularly distributed and of different sizes and shapes.

Color in life. Pale yellowish ground color. Dorsal surface of head dark brown, except for pale yellowish areas on snout tip. Four dark-brown saddles crossing dorsum, reaching longitudinal dark strip on side of trunk: first at dorsal-fin origin, second below dorsal-fin base, third typically at adipose-fin region, and fourth at end of caudal peduncle. Caudal-fin black, with small hyaline circular area on each lobe, tip of lobes hyaline; some specimens with caudal-fin lobe entirely dark (Fig. 3).

Color in alcohol. Similar pattern described for living specimens, but with ground color dark brown (Fig. 1).

Sexual dimorphism. Adult males are distinguished by having a papilla at the urogenital opening (vs. papilla absent in females), and by an unbranched pectoral- and pelvic-fin ray supporting a dermal flap on their proximal dorsal surface in males.

Etymology. The specific name capetinga from the Tupi-guarani dialect is in reference to the old and unused name of São João D'Aliança municipality. The name "capetinga» means white, or clear water. A noun in apposition.

Distribution. Rhinolekos capetinga is known from two localities at the córrego da Branca and one locality at the córrego Roncador, all drainages of the rio Tocantizinho, rio Tocantins basin (Fig. 4a).

Habitat. Rhinolekos capetinga was collected on flat areas of the córrego da Branca and córrego Roncador, rio Tocantins basin, in places of shallow clear waters, about 1 $\mathrm{m}$ depth and median to fast current flow. The fishes captured were associated with the vegetation that covers the bottom and the border of the headwaters (Fig. 4b).

\section{Phylogenetic and time calibrated tree}

Partial sequences of the three mitochondrial genes (16S rRNA, COI, Cytb) and one nuclear gene (F-reticulon 4) were obtained from GenBank (Suppl. material 3 - Table S1) (same data available in Roxo et al. 2014a). The combined sequence data resulted in a matrix of 4,500 base pairs. This matrix was used to perform all phylogenetic and biogeographic analyses. Bayesian and ML phylogenetic analyses resulted in very similar topologies (Suppl. material 1 - Fig. S1). Our results illustrate the same phylogenetic relationship of Roxo et al. (2014) that the clades Hypoptopomatinae, Neoplecostominae and Otothyrinae are monophyletic with strong statistical support $(B S=96, P=0.99$ for Hypoptopomatinae; $\mathrm{BS}=99, \mathrm{P}=1.00$ for Neoplecostominae; $\mathrm{BS}=96, \mathrm{P}=0.99$ with $\mathrm{BI}$ for Otothyrinae). The new species $R$. capetinga formed sister group to the species $R$. garavelloi, and both species formed sister group to the species $R$. britskii. 


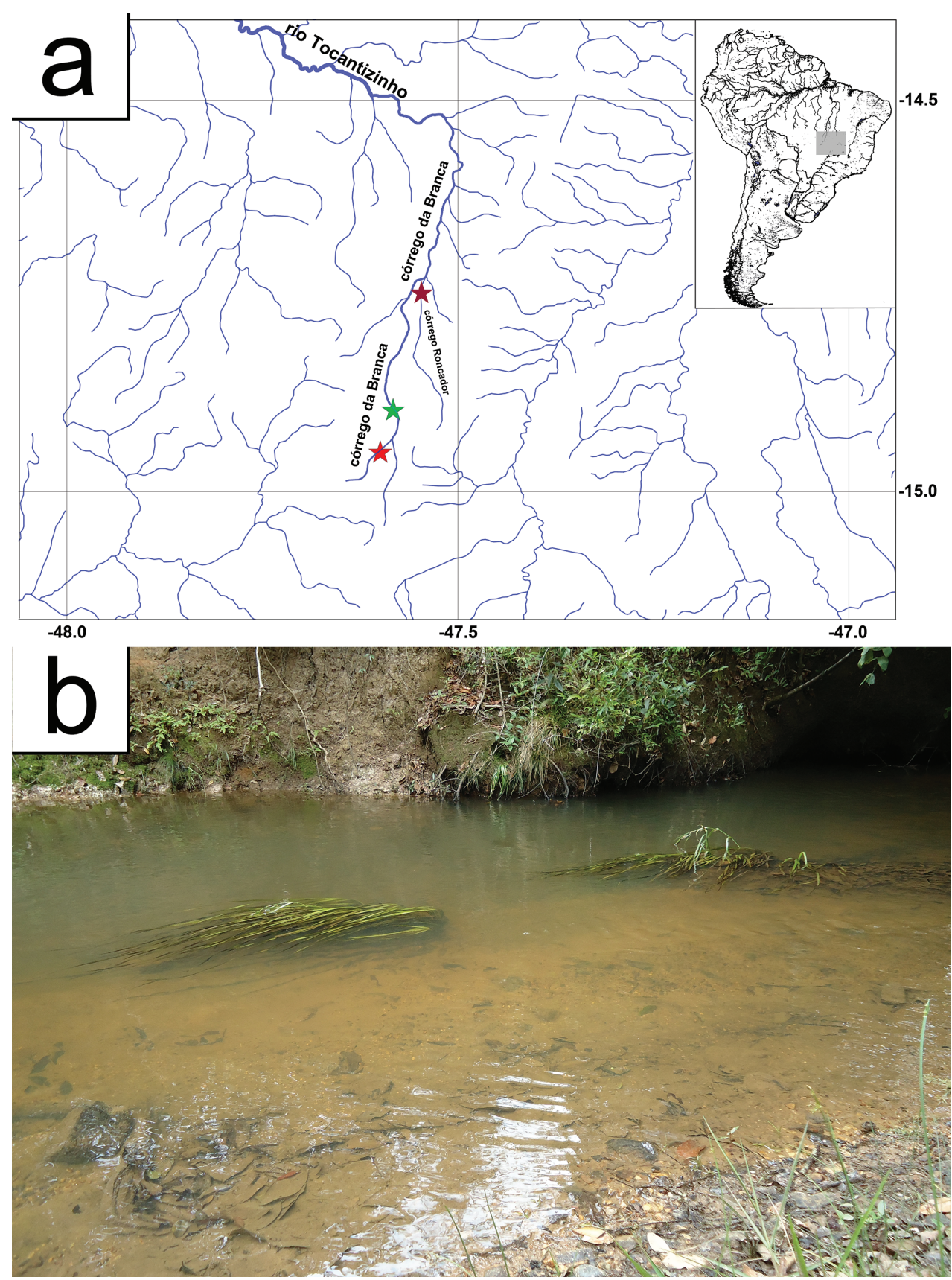

Figure 4. a Map showing the distribution of $R$. capetinga. Type locality at córrego da Branca, green

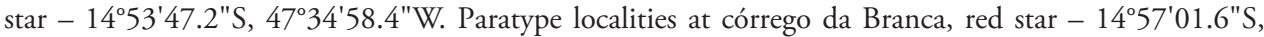

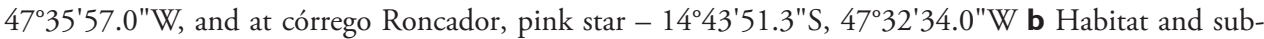
merged vegetation where the specimens were found in type locality of córrego da Branca, $14^{\circ} 53^{\prime} 47.2^{\prime \prime} \mathrm{S}$, 47³4'58.4"W. Photo: LH Roxo. 


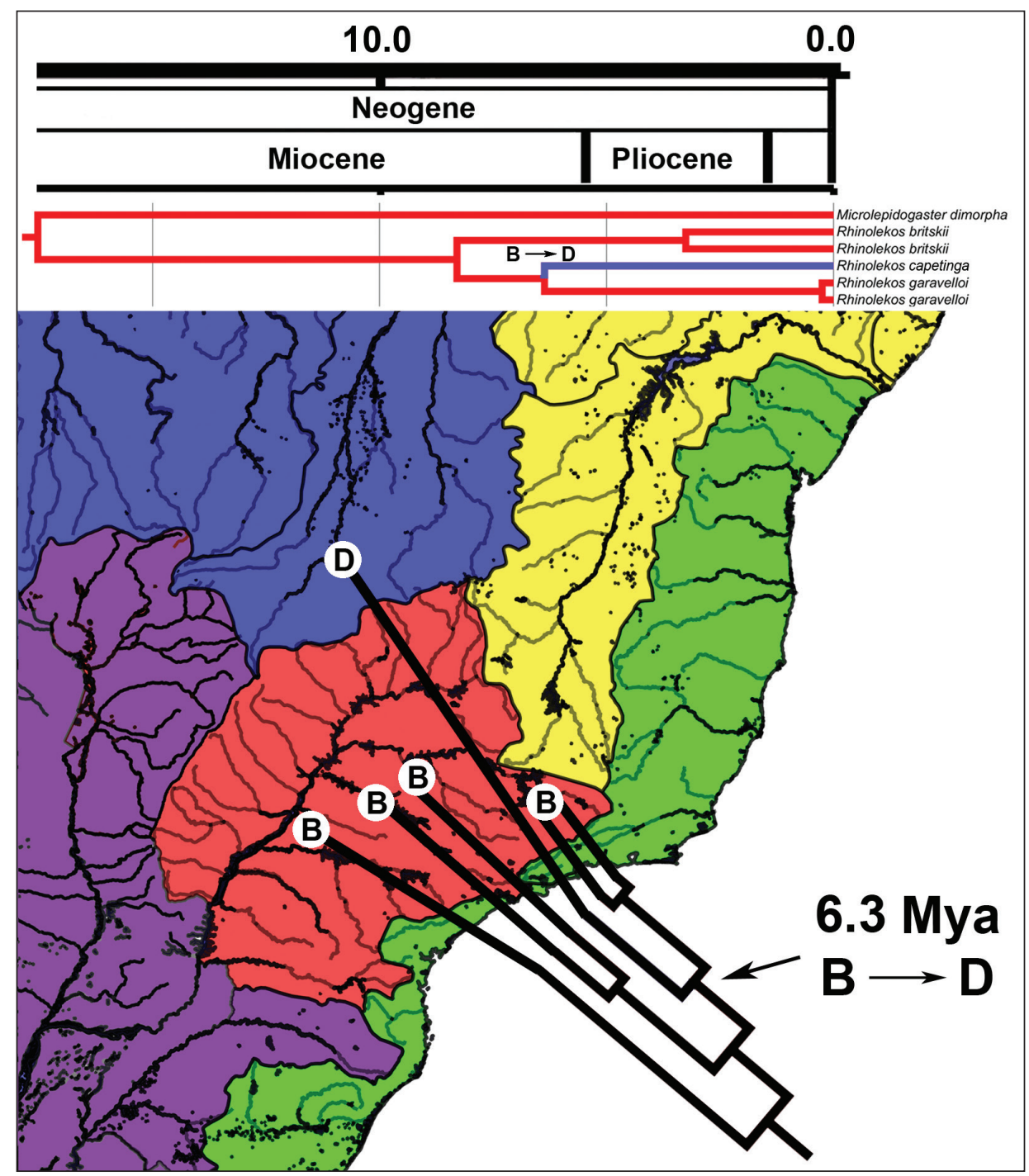

Figure 5. Biogeographic distribution and time-calibrated phylogenetic tree of Microlepidogaster and Rhinolekos species, based on three mitochondrial (16SrRNA, COI, Cytb) and one nuclear marker (F-reticulon 4), modified from figure 7 of Roxo et al. (2014a). The map colorations indicate distinct biogeographic regions according to classification available in Roxo et al. (2014a): Green - Coastal drainages (A); Red - upper rio Paraná basin (B); Purple - Paraguay, Lower Paraná and Uruguay basins (C); Blue - Amazon basin (D); Yellow - São Francisco basin (E).

Our time calibrated phylogeny and the ancestral area reconstruction (Suppl. material 2 - Fig. S2; Fig. 5) suggested that the genus Rhinolekos originated in the upper rio Paraná basin about 17.5 Mya (9.6-27.9 Mya 95\% HPD) and the new species $R$. capetinga reached the area $\mathrm{D}$ (Amazon and Orinoco basins) from drainages of the rio Paranaíba about 6.3 Mya (4.1-13.9 Mya 95\% HPD) at the end of Miocene. 


\section{Discussion}

The new species Rhinolekos capetinga is a typical species of the genus, given that it presents the main characters used by Martins and Langeani (2011a): the lateronasal plate just above second infraorbital, forming anterior distal nostril margin in contact anteriorly with prenasals, and the anterior portion of the compound supraneural-first dorsal-fin proximal radial contacting the neural spine of the $9^{\text {th }}$ vertebrae, a character that, according to Schaefer (1998), is a homoplastic condition evolved independently many times among the Otothyrinae.

Martins and Langeani (2011a) suggested that the presence of the lateronasal plate is a character state that is present not only in Rhinolekos but also shared among species of Acestridium Haseman, 1911 and Gymnotocinclus. The works of Cramer et al. (2011) and Roxo et al. (2014a) suggested that species of these two genera are not closely related to Rhinolekos. Gymnotocinclus was found to be the sister group to the genus Corumbataia Britski, 1997, and Acestridium was included in a polytomy with other Otothyrinae species (Cramer et al. 2011). In contrast, Acestridium was found to be the sister group to Hypoptopoma Günther, 1868 by Roxo et al. (2014a). Considering these hypotheses, the lateronasal plate, the main character used to distinguish Rhinolekos from Microlepidogaster Eigenmann \& Eigenmann, 1889, as proposed by Martins et al. (2011a), is a homoplasy.

The anterior portion of the compound supraneural-first dorsal fin proximal radial contacting the neural spine of the $9^{\text {th }}$ vertebrae (Fig. 2a) is present in the new species $R$. capetinga and that character state is shared with $R$. britskii, the most similar species externally. However, in a phylogenetic and biogeographic study of Hypoptopomatinae, Neoplecostominae, and Otothyrinae, Roxo et al. (2014a) suggested that $R$. capetinga (identified in that study as Rhinolekos sp. 1) form a sister group with $R$. garavelloi, and both species form a sister group with $R$. britskii. This result suggests that the compound supraneural-first dorsal fin proximal radial contacting the neural spine of the $9^{\text {th }}$ vertebrae is a homoplasy, since that in $R$. garavelloi and $R$. schaeferi it contacting the neural spine of the $10^{\text {th }}$ vertebrae. Furthermore, in all other Hypoptopomatinae and Otothyrinae species the compound supraneural-first dorsal fin-proximal radial contacting the neural spine of the $7^{\text {th }}$ vertebrae and in Epactionotus contacting the neural spine of the $8^{\text {th }}$ vertebrae (Martins and Langeani 2011a).

Martins et al. (2014a) reported that the pectoral-fin axillary slit is present in many species of Otothyrinae. Within Rhinolekos, the slit was reported to be absent in adults, but present in juveniles (Martins and Langeani 2011a). However, it was not observed in the new species, even in very young specimens. The complete absence of the pectoral-fin axillary slit is a condition shared with Otothyris travassosi Garavello, Britski \& Schaefer, 1998, O. rostrata Garavello, Britski \& Schaefer, 1998, O. lophophanes (Eigenmann \& Eigenmann, 1889), O. juquiae Garavello, Britski \& Schaefer, 1998, and Schizolecis guntheri (Miranda Ribeiro, 1918) (Martins et al. 2014a), and, according to Reis and Schaefer (1998), its presence is a derived condition in Otothyrinae and its absence is a secondarily derived condition. 


\section{Biogeography and geodispersal route}

Rhinolekos capetinga is the first species of Rhinolekos described in the rio Tocantins basin. Results of Roxo et al. (2014a) suggested that this genus originated in the upper rio Paraná basin at 17.5 Mya (9.6-27.9 Mya 95\% HPD) (also see Suppl. material 2 - Fig. $\mathrm{S} 2$ of the present study). However, in last paper the species $R$. capetinga (Rhinolekos sp. 1 in Roxo et al. 2014a) was erroneously assigned to the B area (upper Paraná River basin). In our study we corrected this misunderstanding and assigned the species $R$. capetinga to the $\mathrm{D}$ area (Amazon and Orinoco basins) during the ancestral area estimation performed in Lagrange and found that dispersal events in the end of the Miocene, about 6.3 Mya (4.1-13.9 Mya 95\% HPD), let the ancestor of $R$. capetinga reach the rio Tocantins basin (Suppl. material 2 - Fig. S2; Fig. 5) from drainages of rio Paranaíba basin.

Several authors (e.g. Eigenmann and Eigenmann 1891; Jordan 1896; Pearson 1937; Carvalho and Albert 2011; Ribeiro et al. 2013) suggested that headwater captures could explain the movement of fish lineages among the rio Paraguay, the Amazon River tributaries (e.g. Madeira, Tocantins and Xingu) and the drainages of the Brazilian Shield (e.g. rio Paranaíba). By definition, headwater captures change the spatial location of a watershed acting simultaneously as a vicariant process and occasioning biological dispersal. This geological process has been widely reported as responsible for fish movement among adjacent drainages (Ribeiro 2006; Albert et al. 2011; Carvalho and Albert 2011; Roxo et al. 2012; Roxo et al. 2014b), and thus for fish movements of the subfamily Otothyrinae (Roxo et al. 2014a).

Lima and Ribeiro (2011) substantiated that the ichthyofauna of the rio Tocantins shares species with the trans-boundary river basins, namely the Paraguay, Paraná, São Francisco, and Xingu drainages. Additionally, Montoya-Burgos (2003) also associated cladogenetic events within species of Hypostomus Lacepède, 1803 with divisions among the rio Amazon tributaries and the Paraguay-Paraná system. Therefore, considering the previous hypothesis, we believe that headwater captures may have influenced the movement of ancestral species of $R$. capetinga from the drainages of the rio Paranaíba to the rio Tocantins at the end of the Miocene (Fig. 5).

\section{Comparative material}

Microlepidogaster arachas Martins, Calegari \& Langeani, 2013: LBP 10882, 3, 22.3-36.3 mm SL, rio Araguari, rio Paranaíba basin; LBP 11724, 9, 38.0-41.2 mm SL, 1 c\&s, $39.1 \mathrm{~mm} \mathrm{SL}$, córrego sem nome, rio Paranaíba basin; Microlepidogaster discus Martins, Rosa \& Langeani, 2014b: MZUSP 115384, 2, 38.8-40.4 mm SL, rio Itacambiruçu, rio Jequitinhonha basin; Microlepidogaster dimorpha Martins \& Langeani, 2011b: LBP 10683, 2, 28.8-35.6 mm SL, rio Uberaba, upper rio Paraná basin; Microlepidogaster longicolla Calegari \& Reis, 2010: LBP 17077, 4, 39.7-46.4 mm SL, rio Pipiripari, upper rio Paranaíba basin; LBP 17060, 39.1-40.2 mm SL, córrego Maria Velha, upper rio Paranaíba basin; Microlepidogaster perforatus Eigenmann 
\& Eigenmann, 1889: LBP 19498, 1, 28.9 mm SL, rio Carandaí, rio São Francisco basin; Rhinolekos britskii Martins \& Langeani, 2011a: LBP 7245, 3, 28.9-30.5 mm SL, rio Arapuca, rio Paranaíba basin; LBP 7253, 15, 21.7-35.2 mm SL, córrego sem nome, rio Paranaíba basin; MZUSP 103698, 6 paratypes, 27.1-36.1 mm SL, córrego sem nome, rio Paranaíba basin; Rhinolekos garavelloi Martins \& Langeani, 2011 a: LBP 7246, 24, 24.1-34.8 mm SL, córrego Fazenda Lageado, rio Paranaíba basin; MZUSP 103697, 5 paratypes, 21.4-31.9 mm SL, córrego da Fazenda Lageado, rio Paranaíba basin; Rhinolekos schaeferi Martins \& Langeani, 2011a: LBP 19460, 1, 28.5 mm SL, córrego Fazenda Garaíbas, rio Paranaíba basin; LBP 19461, 1, 36.6 mm SL, córrego Fazenda Garaíbas, rio Paranaíba basin; Rhinolekos sp.: LBP 7247, 26, 24.1-33.1 mm SL, córrego Fazenda Balsamo, rio Paranaíba basin.

\section{Acknowledgements}

The authors wish to thank Angela M. Zanata, Bruno F. Melo, Jefferson M. Henriques, Luiz H. Roxo, Marcelo Melo, Oswaldo T. Oyakawa, Priscila Camelier, and Renato Devidé for their help during the collection expeditions, Ricardo Britzke for reading the manuscript and giving valuable suggestions and Maria Thereza P. Jorge for the English revision. This research was supported by the Brazilian agencies FAPESP (Fundação de Amparo à Pesquisa do Estado de São Paulo, proc. 2014/05051-5 to FFR, 2014/06853-8 to LEO and 2012/01622-2 to GSCS) and MCT/CNPq (Conselho Nacional de Desenvolvimento Científico e Tecnológico) (Edital Universal, proc. N. 441347/2014-2 coord. FFR).

\section{References}

Albert JS, Petry P, Reis RE (2011) Major biogeographic and phylogenetic patterns. In: Albert JS, Reis RE (Eds) Historical Biogeography of Neotropical Freshwater Fishes. University of California Press, Berkeley, Los Angeles, 21-57. doi: 10.1525/california/9780520268685.003.0002

Albert JS, Reis RE (2011) Historical biogeography of Neotropical freshwater fishes, $1^{\text {st }}$ edn. University of California Press, Berkeley, Los Angeles. doi: 10.1525/california/9780520268685.001.0001

Armbruster JW, Page LM (1996) Redescription of Aphanotorulus (Teleostei: Loricariidae) with description of one new species, $A$. ammophilus, from the Rio Orinoco basin. Copeia 1996(2): 379-389. doi: 10.2307/1446854

Bertuzzo E, Muneepeeraku R, Lynch HJ, Fagan WF, Rodriguez-Iturbe I, Rinaldo A (2009) On the geographic range of freshwater fish in river basins. Water Resour Res 45(11). doi: 10.1029/2009WR007997

Boeseman M (1968) The genus Hypostomus Lacépède 1803, and Surinam representatives (Siluriformes: Loricariidae). Zoologische Verhandelingen 99: 1-89. 
Britski HA (1997) Descrição de um novo gênero de Hypoptopomatinae, com duas espécies novas (Siluriformes, Loricariidae). Papéis Avulsos de Zoologia, São Paulo 40(15): 231-255.

Calegari BB, Reis RE (2010) A new species of Microlepidogaster (Siluriformes: Loricariidae: Hypoptopomatinae) from the upper rio Paraná basin, Brazil. Neotropical Ichthyology 8(3): 625-630.

Carvalho TP, Albert JS (2011) The Amazon-Paraguay Divide. In: Albert JS, Reis RE (Eds) Historical biogeography of Neotropical freshwater fishes. University of California Press, Berkeley, 193-202.

Carvalho TP, Lehmann PA, Reis RE (2008) Gymnotocinclus anosteos, a new uniquely-plated genus and species of loricariid catfish (Teleostei: Siluriformes) from the upper rio Tocantins basin, central Brazil. Neotropical Ichthyology 6(3): 329-338. doi: 10.1590/S167962252008000300006

Carvalho TP, Reis RE (2009) Four new species of Hisonotus (Siluriformes: Loricariidae) from tem upper rio Uruguay, southeastern South America, with a review of the genus in the rio Uruguay basin. Zootaxa 2113: 1-40.

Chiachio MC, Oliveira C, Montoya-Burgos JI (2008) Molecular systematic and historical biogeography of the armored Neotropical catfishes Hypoptopomatinae and Neoplecostominae (Siluriformes: Loricariidae). Molecular Phylogenetics and Evolution 49: 606-617. doi: 10.1016/j.ympev.2008.08.013

Cramer CA, Bonatto SL, Reis RE (2011) Molecular phylogeny of the Neoplecostominae and Hypoptopomatinae (Siluriformes: Loricariidae) using multiple genes. Molecular Phylogenetics and Evolution 59(1): 43-52. doi: 10.1016/j.ympev.2011.01.002

Drummond AJ, Rambaut A (2007) BEAST: Bayesian evolutionary analysis by sampling trees. BMC evolutionary biology 7(1): 214. doi: 10.1186/1471-2148-7-214

Edgar RC (2004) Muscle: a multiple sequence alignment method with reduced time and space complexity. BMC Bioinformatics 5: 1-19. doi: 10.1186/1471-2105-5-113

Eigenmann CH, Eigenmann RS (1889) Description of new nematognathoid fishes from Brazil. West American Scientist 6(42): 8-10.

Eigenmann CH, Eigenmann RS (1891) A catalogue of the freshwater fishes of South America. Proceedings of the United States National Museum 14: 1-81. doi: 10.5479/ si.00963801.842

Eschmeyer W (2014) Catalog of fishes. Electronic publication in "World Wide Web". http:// www.calacademy.org/research/ichthyology/catalog [accessed 23 June 2014]

Eschmeyer WN, Fong JD (2014) Species by Family/Subfamily. http://research.calacademy. org/research/ichthyology/catalog/SpeciesByFamily.asp [accessed 08 October 2014]

Felsenstein J (1985) Confidence limits on phylogenies: an approach using the bootstrap. Evolution 39: 783-791. doi: 10.2307/2408678

Fricke R, Eschmeyer WN (2014) Catalog of fishes. http://research.calacademy.org/research/ ichthyology/catalog/collections.asp [accessed 15 July 2014]

Garavello JC, Britski HA, Schaefer SA (1998) Systematics of the genus Otothyris Myers 1927, with comments on geographic distribution (Siluriformes: Loricariidae: Hypoptopomatinae). American Museum Novitates 3222: 1-19. 
Grant CEH, Lowe WH, Fagan WF (2007) Living in the branches: population dynamics and ecological processes in dendritic networks. Ecology Letters 10: 165-175. doi: 10.1111/j.1461-0248.2006.01007.x

Günther A (1868) Diagnoses of some new freshwater fishes from Surinam and Brazil, in the collection of the British Museum. Annals and Magazine of Natural History 1(6): 475-481. doi: 10.1080/00222936808695733

Hall TA (1999) BioEdit: a user-friendly biological sequence alignment editor and analysis program for Windows 95/98/NT. Nucleic Acids Symposium Series 41: 95-98.

Haseman JD (1911) Descriptions of some new species of fishes and miscellaneous notes on others obtained during the expedition of the Carnegie Museum to central South America. Annals of the Carnegie Museum 7: 315-328.

Huelsenbeck JP, Ronquist F (2001) MrBayes: Bayesian inference of phylogenetic trees. Bioinformatics 17: 754-755. doi: 10.1093/bioinformatics/17.8.754

International Commission on Zoological Nomenclature (1999) International code of zoological nomenclature. Fourth Edition. The International Trust for Zoological Nomenclature, London.

Jordan DS (1896) Science Sketches. AC McClurg and Company, Chicago.

Lacepède BGE (1803) Histoire naturelle des poisons 5: 1-803.

Lima FCT, Ribeiro AC (2011) Continental-Scale Tectonic Controls of Biogeography and Ecology In: Albert JS, Reis RE (Eds) Historical biogeography of Neotropical freshwater fishes. University of California Press, Berkeley, 145-164. doi: 10.1525/ california/9780520268685.003.0009

Lundberg JG (1993) African South America freshwater fish clade and continental drift: problems with a paradigm. In: Goldblatt P (Ed.) The Biotic Relationship between Africa and South America. Yale University Press, 156-199.

Lundberg JG, Sullivan JP, Rodiles-Hernandez R, Hendrickson DA (2007) Discovery of African roots for the Mesoamerican Chiapas catfish,Lacantunia enigmatica, requires an ancient intercontinental passage. Proceedings of the Academy of Natural Sciences of Philadelphia 156: 39-53. doi: 10.1635/0097-3157(2007)156[39:DOARFT]2.0.CO;2

Martins FO, Britski HA, Langeani F (2014a) Systematics of Pseudotothyris (Loricariidae: Hypoptopomatinae). Zoological Journal of the Linnean Society 170(4): 822-874. doi: 10.1111/zoj.12107

Martins FO, Calegari BB, Langeani F (2013) Microlepidogaster arachas, a new species of hypoptopomatine catfish (Siluriformes: Loricariidae) from the upper rio Paraná basin, Brazil. Zootaxa 3608(5): 379-388. doi: 10.11646/zootaxa.3608.5.6

Martins FO, Langeani F (2011a) Rhinolekos, a new genus with three new species of Hypoptopomatinae (Siluriformes: Loricariidae) from upper rio Paraná. Neotropical Ichthyology 9(1): 65-78. doi: 10.1590/S1679-62252011000100004

Martins FO, Langeani F (2011b) Microlepidogaster dimorpha, a new species of Hypoptopomatinae (Siluriformes: Loricariidae) from the upper Rio Paraná system. Neotropical Ichthyology 9(1): 79-86. doi: 10.1590/S1679-62252011000100005

Martins FO, Rosa AC, Langeani F (2014b) Microlepidogaster discus, a new species of Hypoptopomatinae (Siluriformes: Loricariidae) from the rio Jequitinhonha basin, southeastern Brazil. Zootaxa 3873(4): 560-570. doi: 10.11646/zootaxa.3873.5.6 
Miranda Ribeiro A de (1918) Três gêneros e dezessete espécies novas de peixes Brasileiros. Revista do Museu Paulista 10: 631-646.

Montoya-Burgos JI (2003) Historical biogeography of the catfish genus Hypostomus (Siluriformes: Loricariidae), with implications on the diversification of Neotropical ichthyofauna. Molecular Ecology 12(7): 1855-1867. doi: 10.1046/j.1365-294X.2003.01857.x

Muneepeerakul R, Bertuzzo E, Lynch HJ, Fagan WF, Rinaldo A, Rodriguez-Iturbe I (2008) Neutral metacommunity models predict fish diversity patterns in Mississippi-Missouri basin. Nature 453: 220-222. doi: 10.1038/nature06813

Oliveira C, Avelino GS, Abe KT, Mariguela TC, Benine RC, Ortí G, Vari RP, Corrêa e Castro RM (2011) Phylogenetic relationships within the speciose family Characidae (Teleostei: Ostariophysi: Characiformes) based on multilocus analysis and extensive ingroup sampling. BMC Evolutionary Biology 11: 275. doi: 10.1186/1471-2148-11-275

Pearson NE (1937) The fishes of the Beni-Mamoré and Paraguay basin, and a discussion of the origin of the Paraguayan fauna. Proceedings of the California Academy of Sciences 23: 99-114.

Rambaut A, Drummond AJ (2007a) Tracerv1.5. http://beast.bio.ed.ac.uk/Tracer [accessed 04 November 2014]

Rambaut A, Drummond AJ (2007b) TreeAnnotator v1.7.5. http://beast.bio.ed.ac.uk/TreeAnnotator [accessed 09 November 2014]

Ree RH, Moore BR, Webb CO, Donoghue MJ (2005) A likelihood framework for inferring the evolution of geographic range on phylogenetic trees. Evolution 59: 2299-2311. doi: 10.1111/j.0014-3820.2005.tb00940.x

Ree RH, Smith SA (2008) Maximum likelihood inference of geographic range evolution by dispersal, local extinction, and cladogenesis. Systematic Biology 57: 4-14. doi: $10.1080 / 10635150701883881$

Reis RE, Schaefer SA (1998) New Cascudinhos from southern Brazil: systematics, endemism, and relationships (Siluriformes, Loricariidae, Hypoptopomatinae). American Museum Novitates 3254: 1-25.

Ribeiro AC (2006) Tectonic history and the biogeography of the freshwater fishes from the coastal drainages of eastern Brazil: an example of faunal evolution associated with a divergent continental margin. Neotropical Ichthyology 4: 225-246. doi: 10.1590/S167962252006000200009

Ribeiro AR, Carvalho M, Melo ALA (2005) Description and relationship of Otothyropsis marapoama, a new genus and species of Hypoptopomatinae catfish (Siluriformes: Loricariidae) from rio Tietê basin, southeastern Brazil. Neotropical Ichthyology 3(4): 489-498. doi: 10.1590/S1679-62252005000400006

Ribeiro AC, Jacob RM, Silva RRSR, Lima FCT, Ferreira DC, Ferreira KM, Mariguela TC, Pereira LHG, Oliveira C (2013) Distributions and phylogeographic data of rheophilic freshwater fishes provide evidences on the geographic extension of a central-Brazilian Amazonian palaeoplateau in the area of the present day Pantanal Wetland. Neotropical Ichthyology 11: 319-326. doi: 10.1590/S1679-62252013000200010

Ronquist F, Huelsenbeck JP (2003) MrBayes 3: Bayesian phylogenetic inference under mixed models. Bioinformatics 19: 1572-1574. doi: 10.1093/bioinformatics/btg180 
Roxo FF, Zawadzki CH, Alexandrou MA, Costa Silva GJ, Chiachio MC, Foresti F, Oliveira C (2012) Evolutionary and biogeographic history of the subfamily Neoplecostominae (Siluriformes: Loricariidae). Ecology and Evolution 2: 2438-2449. doi: 10.1002/ece3.368

Roxo FF, Albert JS, Silva GS, Zawadzki CH, Foresti F, Oliveira C (2014a) Molecular Phylogeny and Biogeographic History of the Armored Neotropical Catfish Subfamilies Hypoptopomatinae, Neoplecostominae and Otothyrinae (Siluriformes: Loricariidae). PLoS ONE 9(8): e105564. doi: 10.1371/journal.pone.0105564

Roxo FF, Silva GSC, Zawadzki CH, Oliveira C (2014b) Neoplecostomus doceensis: a new loricariid species (Teleostei, Siluriformes) from the rio Doce basin and comments about its putative origin. ZooKeys 440: 115-127. doi: 10.3897/zookeys.440.8203

Schaefer SA (1997) The Neotropical cascudinhos: Systematics and biogeography of the Otocinclus catfishes (Siluriformes: Loricariidae). Proceedings of the Academy of Natural Sciences of Philadelphia 148: 1-120.

Schaefer SA (1998) Conflict and resolution: impact of new taxa on phylogenetic studies of the Neotropical cascudinhos (Siluroidei: Loricariidae). In: Malabarba LR, Reis RE, Vari RP, Lucena ZMS, Lucena CAS (Eds) Phylogeny and classification of Neotropical fishes. Edipucrs, Porto Alegre, 375-400.

Schaefer SA, Provenzano F (1993) The Guyana Shield Parotocinclus: systematics, biogeography, and description of a new Venezuelan species (Siluroidei: Loricariidae). Ichthyological Exploration of Freshwaters 4(1): 39-56.

Stamatakis A, Hoover P, Rougemont J (2008) A rapid bootstrap algorithm for the RAxML web servers. Systematic Biology 57: 758-771. doi: 10.1080/10635150802429642

Sullivan JP, Lundberg JG, Hardman M (2006) A phylogenetic analysis of the major groups of catfishes (Teleostei: Siluriformes) using rag1 and rag2 nuclear gene sequences. Molecular Phylogenetics and Evolution 41: 636-662. doi: 10.1016/j.ympev.2006.05.044

Taylor WR, van Dyke GC (1985) Revised procedures for staining and clearing small fishes and other vertebrates for bone and cartilage study. Cybium 9(2): 107-119.

Ward RD, Zemlak TS, Innes BH, Last PR, Hebert PDN (2005) DNA barcoding Australia's fish species. Philosophical Transactions of the Royal Society B 360: 1847-1857. doi: 10.1098/rstb.2005.1716

Vari RP, Malabarba LR (1998) Neotropical ichthyology: An overview. In: Malabarba LR, Reis RE, Vari R, Lucena ZMS, Lucena CAS (Eds) Phylogeny and Classification of Neotropical Fishes. Edipucrs, Porto Alegre, 1-11. 


\section{Supplementary material I}

\section{Fig. S1}

Authors: Fábio F. Roxo, Luz E. Ochoa, Gabriel S. C. Silva, Claudio Oliveira

Data type: Adobe PDF file

Copyright notice: This dataset is made available under the Open Database License (http://opendatacommons.org/licenses/odbl/1.0/). The Open Database License $(\mathrm{ODbL})$ is a license agreement intended to allow users to freely share, modify, and use this Dataset while maintaining this same freedom for others, provided that the original source and author(s) are credited.

\section{Supplementary material 2}

\section{Fig. S2}

Authors: Fábio F. Roxo, Luz E. Ochoa, Gabriel S. C. Silva, Claudio Oliveira

Data type: Adobe PDF file

Copyright notice: This dataset is made available under the Open Database License (http://opendatacommons.org/licenses/odbl/1.0/). The Open Database License $(\mathrm{ODbL})$ is a license agreement intended to allow users to freely share, modify, and use this Dataset while maintaining this same freedom for others, provided that the original source and author(s) are credited.

\section{Supplementary material 3}

\section{Table S1}

Authors: Fábio F. Roxo, Luz E. Ochoa, Gabriel S. C. Silva, Claudio Oliveira Data type: Microsoft Word document

Explanation note: Species included in the present study.

Copyright notice: This dataset is made available under the Open Database License (http://opendatacommons.org/licenses/odbl/1.0/). The Open Database License $(\mathrm{ODbL})$ is a license agreement intended to allow users to freely share, modify, and use this Dataset while maintaining this same freedom for others, provided that the original source and author(s) are credited. 


\section{Supplementary material 4}

\section{Table S2}

Authors: Fábio F. Roxo, Luz E. Ochoa, Gabriel S. C. Silva, Claudio Oliveira

Data type: Microsoft Word document

Explanation note: Primers used in the present study to amplify partial sequences of F-reticulon 4, 16S rRNA, cytochrome oxidase subunit I (COI) and cytochrome B (CytB).

Copyright notice: This dataset is made available under the Open Database License (http://opendatacommons.org/licenses/odbl/1.0/). The Open Database License $(\mathrm{ODbL})$ is a license agreement intended to allow users to freely share, modify, and use this Dataset while maintaining this same freedom for others, provided that the original source and author(s) are credited.

\section{Supplementary material 5}

\section{Table S3}

Authors: Fábio F. Roxo, Luz E. Ochoa, Gabriel S. C. Silva, Claudio Oliveira

Data type: Microsoft Word document

Explanation note: DEC models tested to estimate distribution ranges inherited by the descending lineages at each node of the tree. The differences between the models are in the rate of dispersal among adjacent and no adjacent areas. ${ }^{*}$ Represent the model used in the analysis.

Copyright notice: This dataset is made available under the Open Database License (http://opendatacommons.org/licenses/odbl/1.0/). The Open Database License $(\mathrm{ODbL})$ is a license agreement intended to allow users to freely share, modify, and use this Dataset while maintaining this same freedom for others, provided that the original source and author(s) are credited. 